\title{
INVESTIGATION OF AN OPERATION AND MAINTENANCE FRAMEWORK IN THE RAILWAY INDUSTRY: A CASE STUDY OF THE MAKASSAR-PAREPARE
}

\author{
Herawati Zetha Rahman ${ }^{1 *}$, Mohammed Ali Berawi ${ }^{2}$, Bambang Susantono ${ }^{3}$, Perdana Miraj ${ }^{1,3}$, \\ Jade Sjafrecia Petroceany ${ }^{1}$, Rosemarie Maya ${ }^{3}$ \\ ${ }^{1}$ Department of Civil Engineering, Faculty of Engineering, Universitas Pancasila, Srengseng Sawah, \\ Jagakarsa, South Jakarta 12640, Indonesia \\ ${ }^{2}$ Department of Civil Engineering, Faculty of Engineering, Universitas Indonesia, Kampus UI Depok, \\ Depok 16424, Indonesia \\ ${ }^{3}$ Center for Sustainable Infrastructure Development, Universitas Indonesia, Kampus UI Depok, Depok \\ 16424, Indonesia
}

(Received: October 2017 / Revised: January 2018 / Accepted: February 2018)

\begin{abstract}
Railways play a significant role in daily life, offering speed, safety and massive capacity for delivering people from one place to another. However, developing countries such as Indonesia are currently encountering problems related to Operation and Maintenance (OM) contracts. Railway operators are mostly experiencing a negative rate of return when operations depend only on farebox revenue. Thus, an alternative approach that includes government involvement should be instigated to improve project performance. This research aims to evaluate the contract agreement between the state, in the form of the Ministry of Transportation, and business entities in the operation and maintenance phase. The Makassar-Parepare railway section on Sulawesi Island is used as a case study. The study uses a combination of qualitative and quantitative approaches that follow three stages: assessing the initial design; generating an alternative OM scheme; and propose a suitable OM scheme. The results indicate five components that should be considered when developing an OM contract, namely the tariff, risk, feasibility, subsidy and period of the contract. The study recommends a five-year contract for operation and maintenance, and the government should assign a business entity to manage available assets in the project.
\end{abstract}

Keywords: Contract; Maintenance; Multi-criteria; Operation; Railway

\section{INTRODUCTION}

Railways are a transportation mode that offers speed, safety and massive capacity for delivering people from one place to another (Berawi et al., 2015; Nash, 2017). Many countries experience significant benefits from their railway networks; for example, India earns $0.29 \%$ per year of income per capita growth from them (Bogart et al., 2015). On the other hand, the rail industry in the UK has been successfully reducing up 7.7 million tonnes of $\mathrm{CO}_{2}$, or equal to 460 million pounds sterling, employs 216,000 people and prevents 865 deaths or serious injuries from road and other accidents per year (Oxera, 2015).

With their high-speed trains, Japan and China are improving connectivity between regions and boosting the national economic portfolio in the global market (Berawi et al., 2017a). Many

\footnotetext{
*Corresponding author's email: zetha.hera@univpancasila.ac.id, Tel: +62-021-7864730, Fax.+62-021-7270128 Permalink/DOI: https://doi.org/10.14716/ijtech.v9i3.813
} 
researchers and academics have attempted to elaborate issues in the railway industry related to technical and financial aspects, and its impact on society and the environment (Popp \& Schiehlen, 2013; He et al., 2015; Qin, 2016).

Developing countries such as Indonesia are currently encountering problems related to maintenance and operation contracts. Operation and maintenance include the train operations, such as the labor element for train operators, and customer-oriented staff to provide full passenger services. They also include the maintainance of infrastructure (e.g., tracks, signaling and stations), and asset renewal to replace components over time.

Operators and investors are expected to take responsibility for running, maintaining and developing the maintenance and operation of the railways. Therefore, the government should have contractual agreements with business entities to provide services and to share the risks associated with projects. The government is mostly involved in particular areas, such as land acquisition, asset transfer, guarantee of revenue, risk and payment, subsidies during the operation stage and the sunk cost to improve project feasibility (Sengupta, 2006; Loo \& Chow, 2006).

Railway operators mostly experience a negative rate of return when operations depend only on farebox revenue. Therefore, an alternative approach that includes government involvement should be taken to improve project performance. This research aims to evaluate contract agreements between the state, through the Ministry of Transportation, and business entities in the operation and maintenance phase. It is expected that investors will earn maximum profits and the public will use the infrastructure, particularly the railways, at reasonable ticket prices.

Operation and maintenance contracts are part of a Public-Private Partnership (PPP) agreement, in which the business entity is paid by the government or state awarding authority to manage a particular infrastructure project. The government may support the contract through regulations or physical traits. In contrast, a private party is mainly responsible for providing services for users by taking into account government policy and regulations.

The World Bank (2016) states that OM contracts are commonly found in the water and sanitation sector. However, several other sectors, such as roads, power and railways, have also successfully implemented this type of contract. It is mostly a short-term agreement of less than ten years. The water sector in Latin America and the Caribbean use 7-15 year OM contracts to operate, manage and maintain public water assets (raw and potable) and some sewerage assets (World Bank, 2005).

The road sector has also adopted OM contracts to manage infrastructure performance. The United States has extensive experience in developing this type of contract and has achieved the expected level of service (Ozbek \& de la Garza, 2011). Most of the contract are use performance-based contracts and give detailed guidance on evaluating contractor performance during the contract. When the level of service is achieved, the contractor has a higher chance of managing the infrastructure in the next contract (Hyman, 2009).

However, contracting out the activities or components of the railways are still limited. Unlike the road sector, railways are facing problems in implementing this type of contract due to limited knowledge and limited supporting regulations. Some countries have been successful in this area, such as the United Kingdom, whose Office of Rail and Road (ORR) has established contracts through a rail licensing regime, supportive legislation and agreements. The state of Victoria in Australia has also attempted to improve rail and tram performance with agreements that outline the roles and responsibilities of the operators and railway authority.

Finland uses fixed price contracts for signaling, tracks and platforms, while the Netherlands uses performance-based contracts for rail maintenance, particularly for selected components 
such as signaling, power supply, tracks and telecommunications (Nyström et al., 2016). As such contracts in the Indonesian railway system are yet to be implemented, it is crucial to establish suitable ones for the sector.

\section{CASE STUDY}

The case study in this research uses the Makassar-Parepare railway section in Sulawesi Island. It is a route of the highest priority and is included on the national railway plan. Its development aims to improve connectivity in the island and provide alternative transportation modes for the people. The project may affect the pattern of industrial development, trade, mining and agriculture, and is forecast to make a significant contribution to regional economic development.
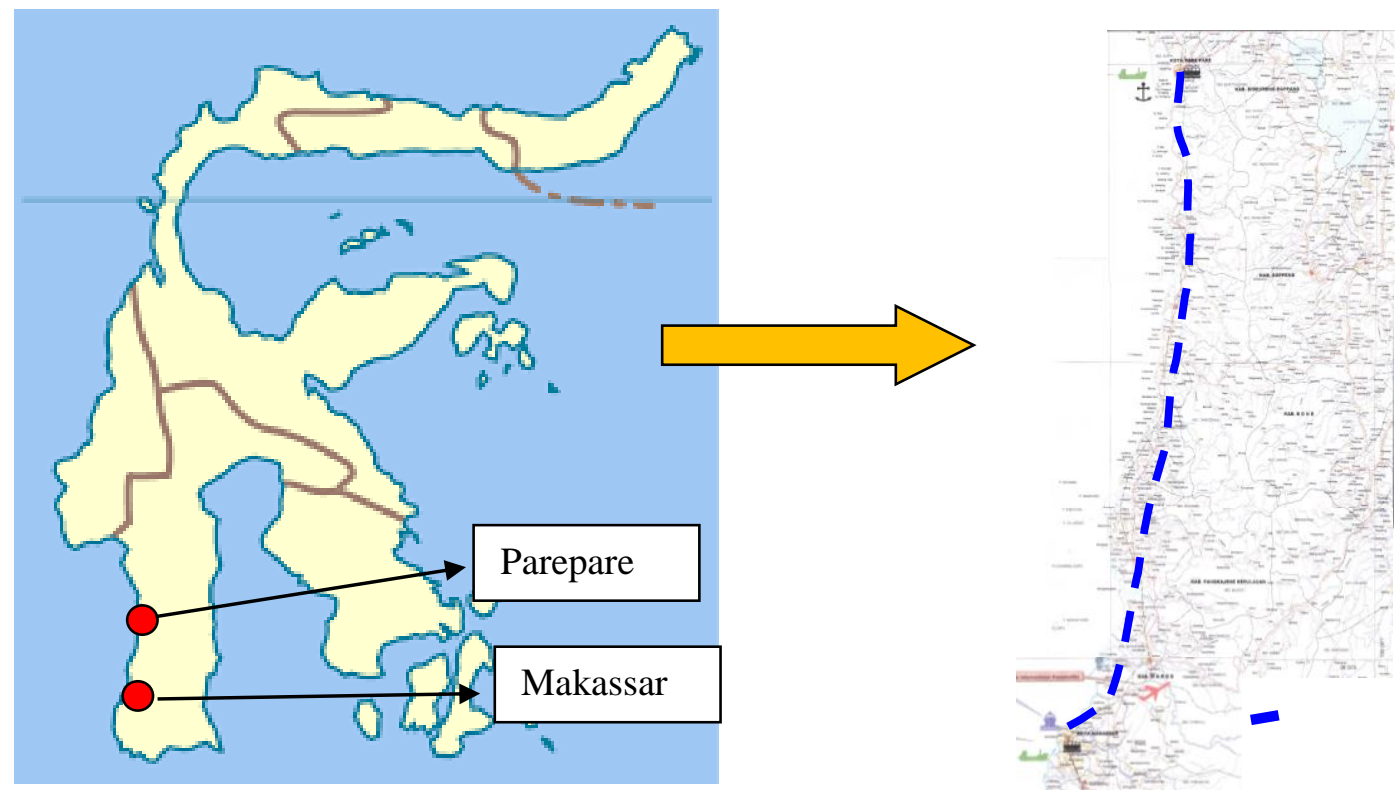

Figure 1 Map of the Makassar-Parepare railway plan

It is estimated that the line will stretch for $145.33 \mathrm{~km}$, with sixteen stations, consisting of five major stations and eleven smaller ones. The investment cost for the infrastructure is about 1.11 trillion rupiahs, or equal to 7.64 billion rupiahs $/ \mathrm{km}$ (Ministry of Transportation, 2012). The railway composition will be divided into two sets of passenger trains and one freight train.

The passenger trains will make four trips per day, while the freight train will make six. In terms of fares, the report from Ministry of Transportation in 2012, proposes 78.8 rupiahs/passenger/km for economy class and 222 rupiahs/passenger/ $\mathrm{km}$ for business class. With a total of $145.3 \mathrm{~km}$, a passenger in economy class will be charged 11,000 rupiahs or equal to US\$ 0.8 , and 30,000 rupiahs or equal to US\$ 2.17 in business class.

\section{METHODOLOGY}

The paper follows three stages to generate the targeted results. In the first stage, data and information regarding the initial design are evaluated (Karim et al., 2007; Berawi et al., 2017b), with the aim to determine operation and maintenance components and costs. The data collection uses a qualitative approach by taking into account secondary data such as journal articles, case studies, government reporst and policy papers (Abdul-Rahman \& Berawi, 2001; Woodhead \& Berawi, 2008). 


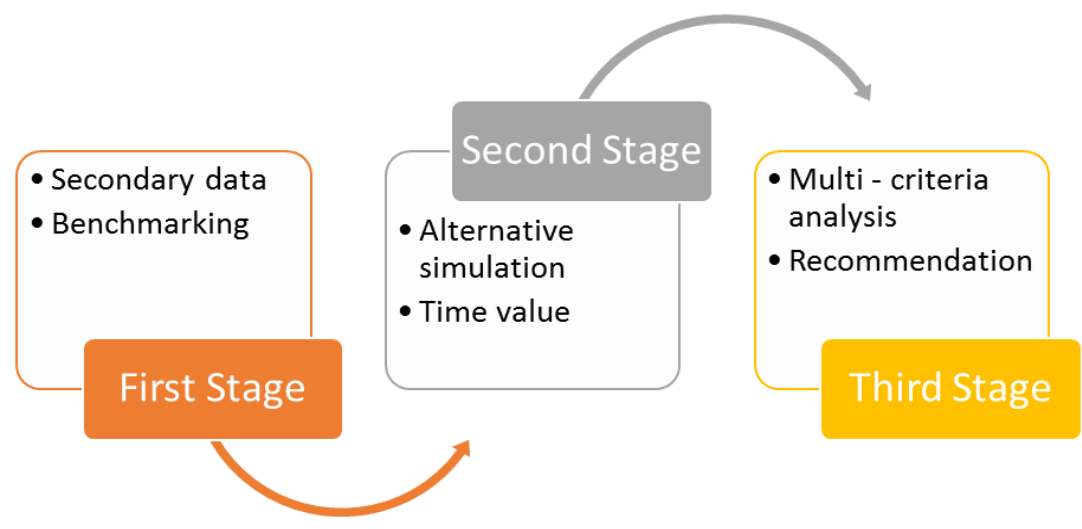

Figure 2 Process of The Research

The second stage proposes a suitable alternative simulation for the operation and maintenance scheme. The calculation involves related costs such as those of operation and maintenance; renewals of infrastructure and purchasing cost of rolling stock depend on the scope of the project. The formula used is as follows:

$$
\cos t \text { in year } A=\frac{\text { index for year } A}{\text { index for year } B} \times \cos t \text { in year } B
$$

The third stage, a Multi-Criteria Analysis (MCA), is conducted to evaluate the most suitable alternative simulation for a project contract. MCA is capable of simplifying problems in the decision-making process by weighting each available criterion and presenting it with a score (Motuziene, et al., 2016; Dojutrek et al., 2016). The method uses a performance matrix in a quantitative manner to generate the best alternative for the project.

The criteria in the research consist of five components: user fares; risk to the government; feasibility for business entities; government subsidies; and contract period. Each criterion has the same weight of $20 \%$. The values for each criterion vary between highly significant, significant, adequate, less significant, and least significant. The scores start at four, up to a maximum of twenty. From the results, the most suitable contract for the railway project development at the operation and maintenance stages will be recommended.

\subsection{Assumption}

In developing the simulation, assumptions of government subsidies, asset transfers, and rolling stock investment are taken into account. The initial analysis evaluates the economy and business class fares from the report. This shows that the proposed charges of 11,000 rupiahs and 30,000 rupiahs are low and may not achieve the expected minimum rate of return from the investors'perspective. For comparison, for another railway section between Jakarta and Bandung with a length of approximately $173 \mathrm{~km}$, three ticket types are available, economy, business and executive, with costs of about 67,000 rupiahs, 80,000 rupiahs and 100,000 to 120,000 rupiahs.

In the study, six simulations are generated and certain assumptions considered. Operation and maintenance costs follow transportation sector inflation of $3.16 \%$ per year, an investment rate of $11 \%$, and a 30 year operation and maintenance cycle. The rolling stock lease is about US\$ 135,000 , or equal to $2,752,442$ rupiahs after conversion with the cost construction index. Thus, assuming the railway section needs 26 trains, the cost will be about 71.56 billion rupiahs. 
The assets are determined by considering the concept design from the unpublished report of the Ministry of Transportation (2012), in which station development will cover about $115 \mathrm{Ha}$. The calculation requires further evaluation and validation to produce a more accurate outcome. This is because the data for each station is unavailable in any published report, Indonesian train station standardization guidelines or ministerial regulation no. 29 of 2011 on the technical requirements for railway station building.

As the stations will be leased, government regulation no. 27 of 2014 on the management of state/local property is used for analysis. The sales value of taxable objects in South Sulawesi ranges from 200,000 rupiahs to 500,000 rupiahs. In this study, an average of 300,000 rupiahs is assumed for the sales value of taxable objects. As a result, investors will pay around 34.5 billion rupiahs/year to the government as non-tax revenue for managing the assets. This cost is very high to be accommodated by business entities, so $10 \%$ of the profits earned from non-core revenue shall be submitted to the government.

The business entities are assumed to generate a minimum revenue of about $30 \%$ from non-core business. The current railway operator is also able to produce a range of between $11 \%$ to over $50 \%$ from non-farebox revenue. An operator managing assets such as JR West in Japan generates 51.22 trillion rupiahs, or equal to a $36 \%$ contribution to the total revenue of the company (JR West, 2014). Thus, the figure is relatively achievable for the prospective operator.

\section{RESULTS AND DISCUSSION}

\subsection{Alternative Simulation}

The first simulation set the ticket price for economy and business class as 55,000 rupiahs and 82,000 rupiahs respectively. Investors were responsible for lease of rolling stock; operation and maintenance of infrastructure and rolling stock; and company overheads. The results show an Internal Rate of Return (IRR) of $15.40 \%$ during the thirty years of the operational stage. Further, the recommended contract was for 20 years, with possible IRR about $15.10 \%$.

In the second simulation, investors were required to invest in the rolling stock and its related components, at a cost of 141.95 billion rupiahs. The ticket prices were set at 63,000 rupiahs for economy class and 82,000 rupiahs for business class. The results show an IRR of $16.89 \%$ during the operational period. The recommended contract was for 15 years, with a potential IRR of $15.28 \%$.

In the third alternative simulation, passengers had to pay 67,000 rupiahs for economy class and 85,000 rupiahs for business class. The railway operators leased the rolling stock at a cost of 71.56 billion rupiahs, with 147.84 billion rupiahs for annual expenditure. The simulation expected to obtain revenue about 164.81 billion rupiahs. Overall, it produced a significant IRR over thirty years of operation, with a positive Net Present Value (NPV).

The scheme subsequently proposed a 5-year operation and maintenance contract, with renewal evaluated by the government through the Ministry of Transportation. During the contract, operators were able obtain an IRR of $17.62 \%$, higher than the investment rate. Furthermore, the government needed to subsidize the economy class to a level of 56,000 rupiah due to the price difference between the economy fare and the expected fare.

In the fourth simulation, the operators gained the right from the government to manage the assets. However, the scheme compensated operators'non-core revenue transfer of $10 \%$ to the government through non-state tax revenues. Thus, the rail operators were responsible for 152.30 billion rupiahs (operation and maintenance costs, overheads and 10\% non-state tax revenue) and obtained revenue of approximately 168 billion rupiahs. The simulation set the economy ticket about 55,000 rupiahs and generates similar IRR and NPV with previous scheme during 
thirty years of operation. However, there was a slight difference in IRR during the 5-year contract of $15.57 \%$.

Furthermore, using the asset management mechanism, the government had no obligation to provide subsidies to the operator. This concept would stimulate the creativity and capability of the operator to generate more revenue from the assets. Instead, the government may reduce the ticket price for passengers; specifically, economy class, from 67,000 rupiahs to 55,000 rupiahs.

In the fifth simulation, the operators no longer lease the rolling stock, but invest through a purchasing mechanism equal to 141.95 billion rupiahs. The investment leads to rolling stock maintenance and freight cars renewals in the twenty- and twenty-five year operation periods of 79.6 billion rupiahs and 207.44 billion rupiahs.

A 5-year OM contract is proposed for the simulation, with an IRR of $15.28 \%$. Compared to the other simulations, the ticket prices are the highest, at 76,500 rupiahs for economy class and 95,000 rupiahs for business class. Thus, the government should provide a substantial subsidy for the economy ticket class.

In the sixth simulation, investors were responsible for rolling stock purchase and also its maintenance. The ticket prices were set at 63,500 rupiahs for economy class and 95,000 rupiahs for business class. The results show a significant rate of return during the 30 year operational stage. Thus a 5-year contract would be used for an agreement, from which investors may gain an IRR of $15.56 \%$. A summary of the six simulations is shown in Table 1.

Table 1 Alternative simulations for generating a suitable OM contract

\begin{tabular}{ccccc}
\hline Scheme* & $\begin{array}{c}\text { Economy Ticket } \\
\text { Price }\end{array}$ & $\begin{array}{c}\text { Business Ticket } \\
\text { Price }\end{array}$ & $\begin{array}{c}\text { IRR 30 Years } \\
(\%)\end{array}$ & $\begin{array}{c}\text { OM Contract } \\
\text { (years) }\end{array}$ \\
\hline A & 55,000 & 82,000 & 15.40 & 20 \\
B & 63,000 & 82,000 & 16.89 & 15 \\
C & 67,000 & 85,000 & $>30$ & 5 \\
D & 55,000 & 85,000 & $>30$ & 5 \\
E & 76,500 & 95,000 & $>30$ & 5 \\
F & 63,500 & 95,000 & $>30$ & 5 \\
\hline
\end{tabular}

Note:
A : Operation and Maintenance + rolling stock lease
$\mathrm{B}$ : Operation and Maintenance + rolling stock investment
$\mathrm{C}$ : Operation and Maintenance + rolling stock lease and government subsidy
D : Operation and Maintenance + asset transfer
E : Operation and Maintenance + rolling stock investment and subsidy
$\mathrm{F}$ : Operation and Maintenance + rolling stock investment and asset transfer

\subsection{Best Alternative}

Five criteria are considered for the analysis, namely tariff, risk, feasibility, subsidy and period of the contract. In terms of the tariff, the score is high when the price shows a similar value to the Willingness To Pay (WTP) or the Ability To Pay (ATP). However, due to the unavailability of primary and secondary data about WTP/ATP, the research assumed 55,000 rupiahs as the baseline, considering similar project development in Indonesia. The score of the tariff will gradually decrease when the tariff is higher than the ATP/WTP value, from 10-14\%, to above $23 \%$ from ATP/WTP.

The risk criterion is related to the government responsibility for supporting the project. The score will be high when the project requires profound changes from the government, such as regulation, assets, or further coordination with other stakeholders. On the other hand, the feasibility criterion considers the rate of return earned by the business entity when operating the 
railway track. The score will be high when the internal rate of return is above $20 \%$. It then decreases to its lowest score when the IRR is below $12 \%$.

The subsidy criterion excludes business and executive classes of passengers, since both of these do not receive any public service obligation from the government. The score is high when no subsidy is involved. Finally, the most suitable contract period is about 3 to 5 years (World Bank, 2016). The score is high when the contract is about three years and the lowest score is when it is over ten years. The criteria can be seen in Table 2 .

Table 2 Criteria and weighting scores for the best alternative

\begin{tabular}{lccccc}
\hline \multirow{2}{*}{ Criterion } & \multicolumn{5}{c}{ Weighting Score } \\
\cline { 2 - 6 } & Similar to & $10-14 \%$ & 12 & 8 & \multicolumn{1}{c}{ - } \\
\cline { 2 - 6 } Tariff & ATP/WTP & ATP/WTP & ATP/WTP & ATP/WTP & ATP/WTP \\
& Very low & Low & Middle & High & Very High \\
Risk & IRR $>20 \%$ & IRR $15-20 \%$ & IRR $= \pm 15 \%$ & IRR $12 \%-15 \%$ & IRR $<12 \%$ \\
Feasibility & None & $+9-12 \%$ from & $+13-16 \%$ from & $+17-20 \%$ from & $>20 \%$ from \\
Subsidy & & tariff & tariff & tariff & tariff \\
& Three years & Five years & Seven years & Ten years & $>10$ years \\
Period of & & & & & \\
\hline
\end{tabular}

Each of the five criteria might generate a different score (twenty to four) in the simulation depending on the result of the description. For instance, simulations $\mathrm{A}$ to $\mathrm{F}$ use different economy ticket prices. That of 55,000 rupiahs will obtain a score of 20 . Higher ticket prices will generate lower scores in the tariff criterion. The weighting score of risk highly depends on the agreement between the private entity and the government. Feasibility, subsidy and period of contract are related to the simulations in Table 1. Higher feasibility, shown by the internal rate of return, obtained a higher score. No subsidy also has a higher score, as does a shorter contract period.

Based on the analysis, option D, an operation and maintenance contract with asset transfer to the business entity, with 88 points, is the highest scoring among the simulations. It is followed by option F, an OM contract with rolling stock investment and asset transfer, and option $\mathrm{A}$, an OM contract with rolling stock lease. The detailed scores can be seen in Table 3.

Table 3 Weighting scores for each alternative simulation

\begin{tabular}{lcccccc}
\hline \multicolumn{1}{c}{ Criterion } & A & B & C & D & E & F \\
\hline Tariff & 20 & 16 & 8 & 20 & 4 & 16 \\
Risk & 12 & 12 & 12 & 12 & 12 & 12 \\
Feasibility & 16 & 16 & 20 & 20 & 20 & 20 \\
Subsidy & 20 & 20 & 4 & 20 & 4 & 20 \\
Period of contract & 4 & 4 & 16 & 16 & 16 & 16 \\
Total Score & 72 & 68 & 60 & 88 & 56 & 84 \\
\hline
\end{tabular}

Note:

A : Operation and Maintenance + rolling stock lease

B : Operation and Maintenance + rolling stock investment

C : Operation and Maintenance + rolling stock lease and government subsidy

$\mathrm{D}$ : Operation and Maintenance + asset transfer

E : Operation and Maintenance + rolling stock investment and subsidy

$\mathrm{F}$ : Operation and Maintenance + rolling stock investment and asset transfer 
Option D is selected as the best alternative for the OM contract because it has a competitive tariff, at only 55,000 rupiahs for economy passengers; acceptable risk; high feasibility, with an IRR of over $20 \%$; no subsidy from the government to support the railway service; and a short contract period of only five years. The findings show a similar contract lengths to the World Bank and other researchers such as Nyström et al. (2016) and Hyman (2009), where most OM contracts are short-term agreements from 5-10 years, which may be extended if the contractor achieves a specific performance.

\section{CONCLUSION}

The Makassar-Parepare Railway Line in South Sulawesi province is a strategic infrastructure aimed at increasing the mobility of the people and improving regional economic development. A robust operation and maintenance contract for the project would play a significant role in attracting investor participation from state-owned enterprises, the private sector, and local enterprises.

The study generated five criteria that should be considered in developing such a contract, namely tariff, risk, feasibility, subsidy and contract period. A five-year contract for operation and maintenance is recommended, and the government should assign a business entity to manage available assets in the project. The scheme offers maximum profits for the business entity of $15.57 \%$ during the five-year operational period, while the government will be able to to maintain economy ticket prices at about 55,000 rupiahs. Business class tickets remain at 85,000 rupiahs to accommodate the higher level of service for users.

The concept is also able to stimulate the creativity and capability of the operator to generate more revenue from the asset rights. Finally, the paper suggests further evaluation of the regulation arrangement and institutional framework to support the legal standing of the contractual agreement between the related parties.

\section{ACKNOWLEDGEMENT}

The author wishes to thank the Ministry of Research and Higher Education and the Directorate of Investment - Directorate General of Railways, Ministry of Transportation, the Republic of Indonesia, for their generous support in the conducting of the research.

\section{REFERENCES}

Abdul-Rahman, H., Berawi, M.A., 2001. "Power Quality System”, A New System of Quality Management for Globalization: Towards Innovation and Competitive Advantages. Quality Assurance (San Diego, Calif.), Volume 9(1), pp. 5-30

Berawi, M.A., Miraj, P., Berawi, A.R.B., Akbar, F., 2017a. A Benchmark Study for Indonesia's High Speed Train Considering Technology Selection. Advanced Science Letters, Volume 23(7), pp. 6343-6346

Berawi, M.A., Zagloel, T.Y., Miraj, P., Mulyanto, H., 2017b. Producing Alternative Concept for the Trans-Sumatera Toll Road Project Development using Location Quotient Method. Procedia Engineering, Volume 171, pp. 265-273

Berawi, M.A., Berawi, A.R.B., Prajitno, I., Nahry, N., Miraj, P., Abdurachman, Y., Tobing, E., Ivan, A., 2015. Developing Conceptual Design of High Speed Railways using Value Engineering Method: Creating Optimum Project Benefits. International Journal of Technology, Volume 6(4), pp. 670-679

Bogart, D., Chaudhary, L., Herranz-Loncán, A., 2015. The Growth Contribution of Colonial Indian Railways in Comparative Perspective. SSRN Electronic Journal 
Dojutrek, M.S., Dojutrek, M.S., Labi, S., Labi, S., Dietz, J.E., Dietz, J.E., 2016. A MultiCriteria Methodology for Measuring the Resilience of Transportation Assets. International Journal of Disaster Resilience in the Built Environment, Volume 7(3), pp. 290-301

He, G., Mol, A.P., Zhang, L., Lu, Y., 2015. Environmental Risks of High-speed Railway in China: Public Participation, Perception and Trust. Environmental Development, Volume 14, pp. 37-52

Hyman, W.A., 2009. Performance-based Contracting for Maintenance (PBCM). No. Project 20-5 (Topic 37-09)

JR West, 2014. Annual Report 2014. West Japan Railway Company

Karim, S.B.A., Rahman, H.A., Berawi, M.A., Jaapar, A., 2007. A Review on the Issues and Strategies of Stakeholder Management in the Construction Industry. In: Meeting and Conference on Management in Construction and Researchers Association (MICRA)

Loo, B.P., Chow, S.Y., 2006. Sustainable Urban Transportation: Concepts, Policies and Methodologies. Journal of Urban Planning and Development, Volume 132(2), pp. 76-79

Ministry of Transportation, 2012. Basic Design of Railway Development between Makassar to Parepare (Unpublished Report)

Motuzienė, V., Rogoža, A., Lapinskienė, V., Vilutienė, T., 2016. Construction Solutions for Energy Efficient Single-family House based on its Life Cycle Multi-criteria Analysis: a Case Study. Journal of Cleaner Production, Volume 112(1), pp. 532-541

Nash, C., 2017. Enhancing the Cost-benefit Analysis of High-speed Rail. High-speed Rail and Sustainability: Decision-making and the Political Economy of Investment, pp. 163

Nyström, J., Nilsson, J.E., Lind, H., 2016. Degrees of Freedom and Innovations in Construction Contracts. Transport Policy, Volume 47, pp. 119-126

Oxera, 2015. What is the Contribution of Rail to the UK economy?

Ozbek, M.E., de la Garza, J.M., 2011. Comprehensive Evaluation of Virginia Department of Transportation's Experience with its First Performance-based Road-Maintenance Contract. Journal of Transportation Engineering, Volume 137(12), pp. 845-854

Popp, K., Schiehlen, W., 2013. System Dynamics and Long-term Behaviour of Railway Vehicles, Track And Subgrade, Volume 6, Springer Science \& Business Media

Qin, Y., 2016. China's Transport Infrastructure Investment: Past, Present and Future. Asian Economic Policy Review, Volume 11(2), pp. 199-217

Sengupta, U., 2006. Government Intervention and Public-Private Partnerships in Housing Delivery in Kolkata. Habitat International, Volume 30(3), pp. 448-461

Woodhead, R.M., Berawi, M.A., 2008. An Alternative Theory of Idea Generation. International Journal of Management Practice, Volume 3(1), pp. 1-19

World Bank, 2005. Water and Wastewater Operations and Maintenance Agreement-Example 1

World Bank, 2016. Management/Operation and Maintenance Contracts. Public-PrivatePartnership in Infrastructure Resource Center. 